\title{
FENOMENA PERMAINAN MINI BRIDGE DI GABSI JEMBER
}

\author{
TOPO YONO \\ topoyono@unmuhjember.ac.id \\ Dosen Prodi Pendidikan Olahraga Universitas Muhammadiyah Jember
}

\begin{abstract}
ABSTRAK
Dalam bermain bridge, pemain harus melalui proses bermain mini bridge terlebih dahulu. Pemain, sebelum dapat menguasai cara bermain, harus mengenal High Card Point (HCP), nama-nama kartu, bidding shet, score shet, ini dasar dari permainan mini bridge. Mini bridge adalah jalan untuk belajar bridge. penelitian ini mengungkapkan fenomena keberadaan dan perkembangan Permainan mini bridge di Kabupaten Jember. Permainan mini bridge sejak awal hadir di Kabuupaten Jember menunjukkan perubahan yang cukup baik. Hal ini dibuktikan dengan munculnya salah satu program yang diluncurkan oleh PB GABSI Kabupaten Jember bekerja sama dengan Dinas Pendidikan dan Kebudayaan Kabupaten Jember yaitu memasyarakatkan olahraga bridge disekolah-sekolah dari tingkat SD sampai SMA yang dikenal dengan istilah BMS yaitu bridge masuk sekolah. Model instruksi dalam permainan mini bridge dapat digunakan dan dipraktekkan secara mudah oleh pemain, terutama pemain pemula di GABSI Jember. Fenomena perkembangan permainan mini bridge di Kabupaten Jember dapat dibuktikan dari hasil yang sudah memenuhi kriteria valid yaitu memenuhi kriteria cukup valid untuk pemain kelompok kecil (uji coba tahap I) memperoleh 74,11\%, dan memenuhi kriteria valid untuk pemain mini bridge kelompok besar (ujicoba tahap II) memperoleh $87,50 \%$.
\end{abstract}

Keyword: Permainan mini bridge, High Card Point, bidding sheet, score sheet.

\section{PENDAHULUAN}

Olahraga prestasi adalah olahraga yang membina dan mengembangkan olahragawan secara terencana, berjenjang, dan berkelanjutan melalui kompetisi untuk mencapai prestasi dengan dukungan ilmu pengetahuan dan teknologi, sebagaimana dimaksud dalam Pasal 1 ayat (13) Undang-undang Nomor 3 Tahun 2005 tentang Sistem Keolahragaan Nasional. Namun pada kenyataan secara empiris, minimnya pembelajaran yang diselenggarakan dalam permainan olahraga menyebabkan jenis olahraga tertentu tidak berkembang secara baik, termasuk permainan mini bridge yang belum dapat dimainkan oleh siapa saja.

Pada pertengahan tahun 2003, Pengurus besar Gabungan Bridge Seluruh Indonesia (GABSI) telah menemukan cara untuk memasyarakatkan olahraga ini. Untuk mengatasi problem mengajarkan bridge telah ada mini bridge yang sangat mudah dipelajari. Agar olahraga ini dianggap bermanfaat. Pengurus Besar (PB) GABSI menjalin kerjasama dengan Kementrian Pendidikan dan kebudayaan (Kemendikbud) dalam memasyarakatkan permainan mini bridge di Indonesia. Kemendikbud bersedia bekerjasama karena yakin bahwa olahraga bridge secara langsung mengasah dan meningkatkan kecerdasan otak manusia, meliputi Kecerdasan Intelektual (IQ), Kecerdasan Emosional (EQ), Kecerdasan Spritual (SQ) serta secara tidak langsung 
meningkatkan kemampuan daya tahan fisik karena setiap pertandingan membutuhkan waktu berjam-jam. Zona, (2017: 1).

Bridge merupakan salah satu jenis olahraga otak yang memungkinkan masyarakat Indonesia untuk berprestasi di tingkat Internasional. Bridge merupakan salah satu cabang olahraga yang mengedepankan semangat kerjasama, kejujuran, dan disiplin. Melalui olahraga ini, kita dapat meningkatkan kemampuan dalam menggunakan logika, imajinasi, memori serta intuisi dengan penalaran serta berpikir positif dan analitis.

Olahraga bridge di Indonesia berada di bawah naungan induk organisasi GABSI yang berdiri sejak tahun 1953. Sejak kehadirannya di Indonesia, permainan bridge tidak serta merta mengalami perkembangan yang pesat, termasuk juga yang terjadi di Kabupaten Jember Jawa Timur. Banyak upaya sudah dilakukan tetapi hasilnya tidak berarti secara signifikan, Bahkan GABSI sendiri telah berusaha untuk melakukan pemasalan dan pembinaan olahraga Bridge dalam rangka menggali prestasi se-maksimal mungkin sejak dini untuk mencapai hasil terbaik di masa yang akan datang.

Target atlet bridge Jatim untuk meraih mendali emas di kejuaraan nasional bridge Jakarta 2016. Upaya yang sudah dilakukan belum juga mendapatakan prestasi yang membanggakan, pemain hanya mampu meraih mendali perak di kejuaraan tersebut. Dari kekalahan tersebut atlet bridge Jawa Timur terancam tidak dikirim mengikuti Pekan Olahraga Nasional. Fenomena kelemahan dan kekalahan pemain ini menggambarkan bagimana perkembangan permainan bridge di jawa timur, termasuk Kabupaten Jember.

Keterampilan teknik bermain bridge sebenarnya dapat dipelajari oleh seseorang dalam satu bulan atau bahkan lebih dengan dibimbing oleh ahli. Faktor sulitnya penguasaan teknik bermain bridge dan terbatasnya orang-orang yang menguasai bermain secara benar mengakibatkan terhambatnya perkembangan penguasaan permainan mini bridge. Berdasarkan uraian-uraian kondisi permainan bridge di Jawa Timur khususnya di kabupaten Jember, maka penting untuk mendeskripsikan secara ilmiah tentang fenomena perkembangan permainan mini bridge di Kabupaten Jember. Deskripsi meliputi permasalahan di lapangan, pola pembelajaran, peningkatan kemampuan bermain, baik pemain maupun pelatih.

\section{KAJIAN PUSTAKA}

Langkah-langkah dalam permainan mini bridge antara lain: (1) Semua pemain duduk berhadapan dengan partner/teman pasangannya yaitu Utara berhadapan dengan Selatan (US) dan Timur berhadapan dengan Barat (TB), (2) Mengambil kartu yang disediakan dalam papan kartu (board), (3) Mensortir kartu dalam genggaman supaya lawan (defender) tidak mengetahui kartu yang dipegang, (4) Pemain menghitung point yang dimiliki, (5) Menuliskannya ke bidding sheet/ kertas penawaran untuk mengetahui berapa besar point yang dimiliki untuk ditambahkan dengan point partner/teman point yang tinggi, (6) Menentukan kontrak, (7) Declarer menjalankan permainan dimulai dengan lead/kartu pembuka sebelah kiri declarer posisi kartu tertutup diatas meja, (8) Dummy membuka seluruh kartu pegangan, (9) Lead dibuka oleh lawan, pertanda 
permainan dimulai. Permainan dimulai dengan mengeluarkan kartu searah jarum jam secara bergantian tidak boleh mendahului dan harus menunggu giliran. Siapa yang memenangkan permainan, berhak mengeluarkan kartu selanjutnya sesuai kehendak dan pemain mengikuti permintaannya. Permainan berakhir setelah seluruh kartu dimainkan, (10) Pemain menuliskan nilai ke score sheet sesuai dengan kartu yang dimenangkan. Bila menang, kartu dalam posisi portrait, tapi jika kartu kalah maka dalam posisi landscape. Yang dihitung adalah kartu yang posisinya portrait lalu dijumlahkan kemudian memasukan skor kedalam table score sheet.

Dalam bermain mini bridge ada kemudahan yang dalam memulai bermain bridge yaitu langsung tanpa harus mengetahui peraturan penawaran (bidding). Semua yang dapat dipelajari dalam mini bridge adalah sama dengan permainan bridge sebenarnya seperti: menghitung point dari kartu yang dipegang $(H C P)$, bagaimana memperoleh trik yang banyak, kontrak tingkat game dan partscore, serta scoring. Andre, (2012: 1).

Mini Bridge dapat dikelompokkan menjadi 7 bagian, yaitu pengenalan $H C P$, nama kartu proses bidding (menawar kontrak), lead, play dan penskoran.

\section{a. High Card Point ( HCP )}

Menurut Iskandar (2004: 3), high card point adalah point yang dimiliki dalam kartu atau honorsnya, yaitu ace memiliki point 4, king 3, queen 2, jack 1.

\section{b. Nama Kartu}

Menurut Iskandar (2004: 1), nama kartu dalam permainan mini bridge yaitu spade, heart, diamond, club.

\section{c. Bidding/ Kontrak}

Menurut Asbi (2010: 34), bidding adalah proses penawaran. Sedangkan Iskandar (2004: 5) menyatakan bahwa dalam permainan mini bridge ada dua jenis kontrak yaitu kontrak tidak game dan kontrak game. Lalu ada kontrak dengan kartu truff dan kontrak tanpa kartu truff. Menurut Asbi (2004: 33) tingkat kontrak dibagi menjadi 4 kelompok yaitu: part score, game, small slam, grand slam, sehingga kontrak sangat berhubungan dengan nilai bonus yang diperoleh. Menurut Hombokau (2004: 1), kontrak dibedakan untuk kontrak major spade dan heart, minor club dan diamond. Menurut Iskandar (2004: 9-10), kontrak tidak game di awal permainan declarer diharuskan menentukan kontrak game atau tidak game. Jika declarer memutuskan untuk tidak bermain game maka ia menuliskan angka satu dikolom kontrak yang disediakan. Pada permainan tidak game declarer berkewajiban paling sedikit mengumpulkan 7 trik.

Gambar 2.1 Bidding Sheet kontrak IH menurut Iskandar (2004: 9). 


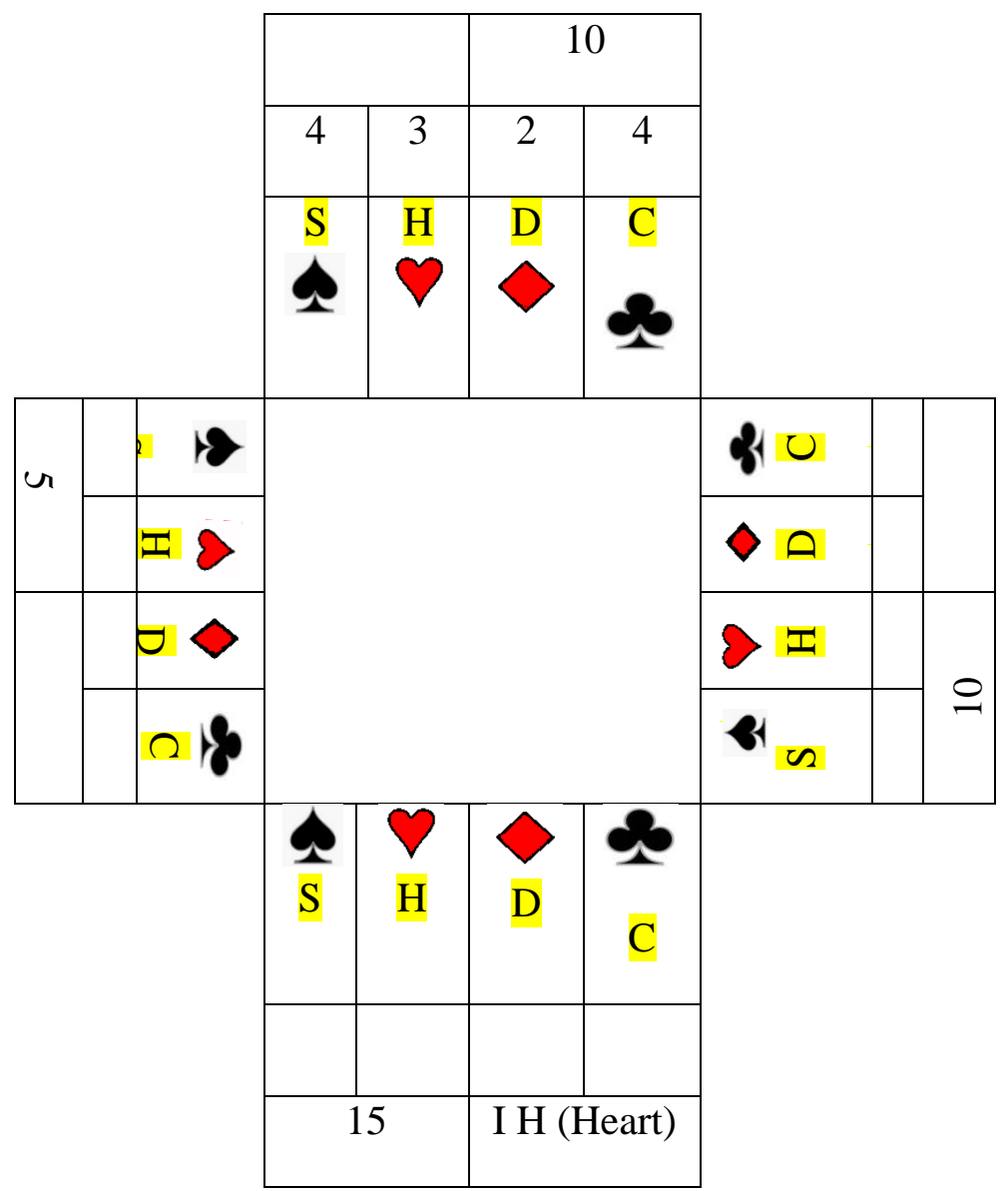

Pada gambar ini declarer menuliskan $1 \mathrm{H}$, maka ia wajib mengumpulkan sedikitnya 7 trick dan heart ditentukan sebagai kartu truff. Jika ia berhasil maka ia akan memperoleh skor berdasarkan tabel dibawah ini:

Tabel 2.3 Tabel Score Tidak Game menurut Iskandar, (2004: 10)

\begin{tabular}{|c|c|c|c|}
\hline \multirow{2}{*}{ TRIK } & \multicolumn{3}{|c|}{ TIDAK GAME } \\
\cline { 2 - 4 } & C/D & H/S & NT \\
\hline 7 & 70 & 80 & 90 \\
\hline 8 & 90 & 110 & 120 \\
\hline 9 & 110 & 140 & 150 \\
\hline 10 & 130 & $\mathbf{1 7 0}$ & 180 \\
\hline 11 & 150 & 200 & 210 \\
\hline 12 & 150 & 200 & 210 \\
\hline
\end{tabular}




\begin{tabular}{|l|l|l|l|}
\hline 13 & 170 & 230 & 240 \\
\hline
\end{tabular}

Jika ternyata declarer berhasil mengumpulkan sepuluh trick maka ia akan mendapatkan skor sebesar 170, berdasarkan tabel diatas.

Menurut Iskandar (2004: 10) kontrak game declarer dapat juga menentukan kontrak tidak game diawal permainan, dengan tujuan mendapatkan skor yang lebih besar. Jumlah trick yang harus dikumpulkan untuk kontrak game adalah sebagai berikut:

Tabel 2.4 Tabel Kontrak Game menurut Iskandar, (2004: 10)

\begin{tabular}{|l|l|l|}
\hline Game & $\begin{array}{c}\text { Dikolom kontrak } \\
\text { dituliskan }\end{array}$ & $\begin{array}{c}\text { Jumlah Trick } \\
\text { yang harus dikumpulkan }\end{array}$ \\
\hline NT & $3 \mathrm{NT}$ & 9 Trick \\
\hline $\mathbf{2}$ & $4 \mathrm{~S}$ & 10 Trick \\
\hline $\boldsymbol{0}$ & $4 \mathrm{H}$ & 10 Trick \\
\hline & $5 \mathrm{D}$ & 11 Trick \\
\hline $\mathbf{2}$ & $5 \mathrm{C}$ & 11 Trick \\
\hline
\end{tabular}

Tabel 2.5 Tabel Score Tidak Game menurut Iskandar, (2004: 10)

\begin{tabular}{|c|c|c|c|c|}
\hline \multirow{2}{*}{ LEVEL } & \multirow{2}{*}{ TRICK } & \multicolumn{3}{|c|}{ GAME } \\
\cline { 3 - 5 } & & $\mathrm{C} / \mathrm{D}$ & $\mathrm{H} / \mathrm{S}$ & $\mathrm{NT}$ \\
\hline 1 & 7 & & & \\
\hline 2 & 8 & & & \\
\hline 3 & 9 & & & 400 \\
\hline 4 & 10 & & 420 & 430 \\
\hline 5 & 11 & 400 & 450 & 460 \\
\hline 6 & 12 & 420 & 480 & 490 \\
\hline 7 & 13 & 440 & 510 & 520 \\
\hline
\end{tabular}


Tabel 2.6 Distribusi kartu Mini Bridge sebelum melakukan bidding menurut Iskandar (2004: 5).

\begin{tabular}{|c|c|}
\hline $\begin{array}{l}\text { S : K } 86 \\
\text { H : A } 7 \\
\text { D : K } 542 \\
\text { C : } 8632 \\
\text { Point }=10\end{array}$ & $\begin{array}{l}\text { S : A } 54 \\
\text { H : K } 62 \\
\text { D : } 973 \\
\text { C : K Q J } 10 \\
\text { point }=13\end{array}$ \\
\hline $\begin{array}{l}\text { S : Q J } 1032 \\
\text { H : J } 1083 \\
\text { D : A } 6 \\
\text { C: A } 4 \\
\text { Point }=12\end{array}$ & $\begin{array}{l}\text { S: } 97 \\
\text { H : Q } 954 \\
\text { D : Q J } 108 \\
\text { C: } 975 \\
\text { Point }=5\end{array}$ \\
\hline
\end{tabular}

Gambar 2.2 Bidding sheet Mini Bridge menurut Iskandar (2004: 6).

$\mathrm{U}$

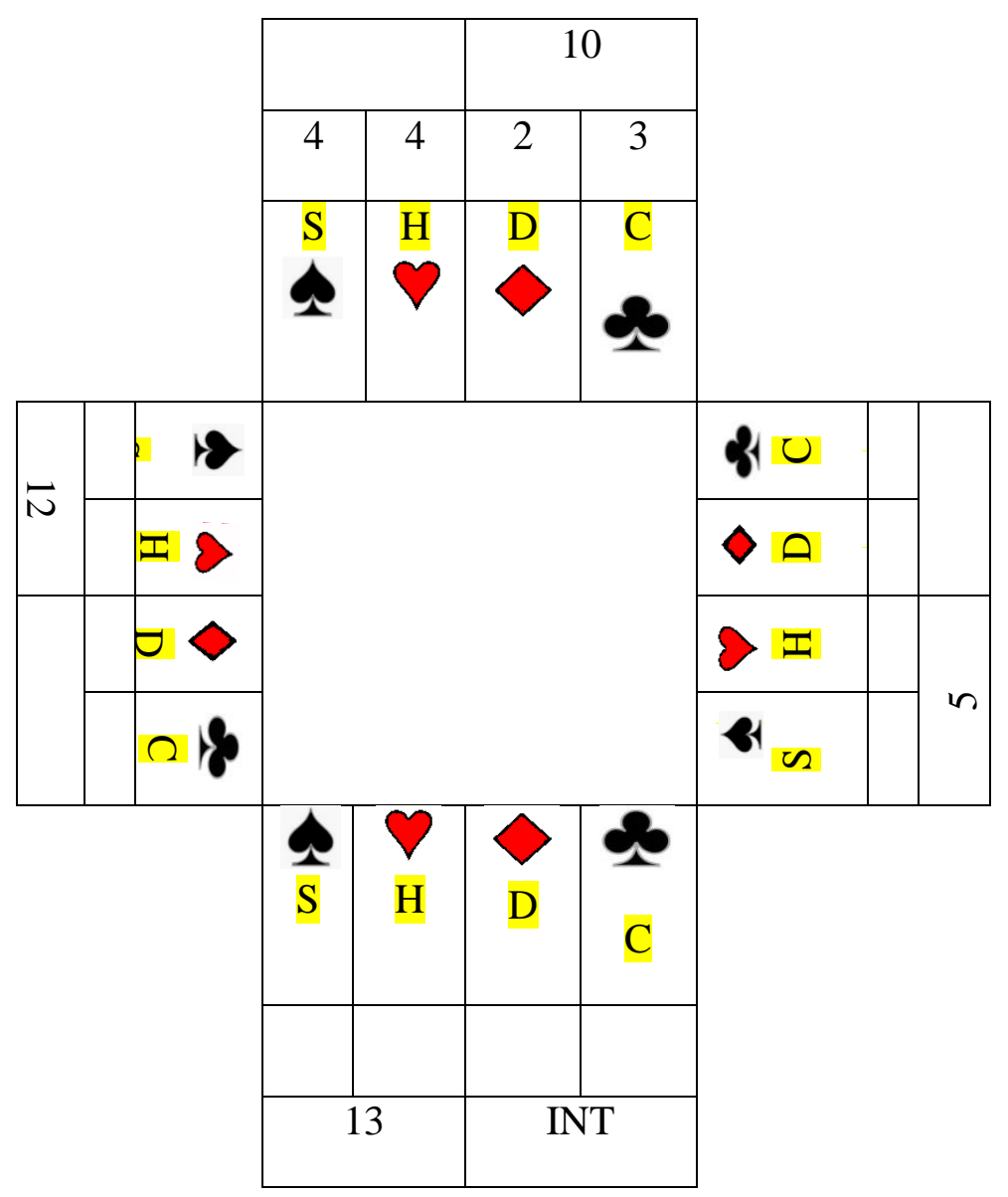

Keterangan: 


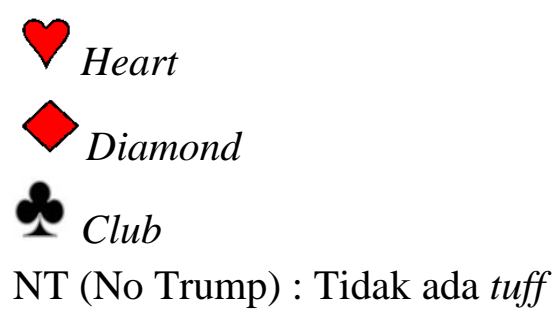

Bidding atau penawaran setelah ditambahkan point utara dan selatan tidak sampai 25 dimana kontraknya 1 NT kontrak tidak game harus memenagkan trik 7. Ini menjadi tugas declearer atau bos untuk mencapai kontrak yang telah disepakati.

\section{e. Declarer}

Menurut Iskandar (2004: 4), declarer adalah pemegang kontrak yang berusaha mencari trick sesuai kontraknya.

\section{f. Lead}

Menurut Iskandar (2004: 2), lead adalah mengeluarkan kartu pertama sebelah kiri declarer mengeluarkan kartu untuk trik pertama. Selanjutnya yang mengeluarkan kartu pertama adalah si pemegang trick kartu pembuka yang ditutup di atas meja dengan posisi potrait atau tegak berdiri, ini sebagai awal permainan. Apabila kartu yang ditutup di buka oleh defender, maka permainan sudah di mulai apa yang di leadkan lawan, pihak declarer harus mengikuti jika kartu lead yang di buka spade kartu yang di keluarkan adalah spade, yang melakukan lead adalah sebelah kiri declarer atau bos. Permainan berputar searah jarum jam secara bergantian mengeluarkan kartu tidak boleh mendahului mengeluarkan kartu sesuai dengan giliran.

\section{g. Play}

Menurut Asbi (2010: 17), play adalah setelah diketahui siapa yang menjadi declarer, lalu pemain yang duduk di sebelah kiri declarer memulai permainan. Ia yang harus memainkan kartu pertama. Pemain yang menurunkan kartu pertama disebut opening leader, jika selatan sebagai declarer, maka barat adalah opening leader. Setelah opener memainkan kartu pertama, partner dari declarer (yang duduk depan declarer) membuka semua kartunya, menyusun di meja, menghadap ke arah partnernya. Partner declarer di sebut dummy hanya kartu dummy yang di buka di meja, sedangkan ketiga pemain lainnya memegang kartunya masing-masing. Dummy selanjutnya tidak berperan aktif dalam proses permainan seterusnya. Setelah Barat memainkan kartu pertama, selanjutnya Utara mendapatkan giliran berikutnya (searah jarum jam), tapi declarer yang menentukan kartu apa yang dimainkan. Selanjutnya giliran Timur, yang diikuti Selatan (declarer). Jadi, declarer memainkan 2 pegangan (Utara dan Selatan) melawan kedua lawannya disebut defender yang memainkan kartunya masing-masing. Pemain yang lead menentukan warna apa yang dimainkan. Contohnya, jika Barat turun dengan diamond, maka Utara, Timur, dan Selatan harus turun kartu diamond, kecuali tentu saja jika ia tidak memiliki warna yang diminta.

Selama permainan, secara bergiliran (searah jarum jam), setiap pemain meletakkan sebuah kartu diatas meja didepannya. Setiap kali keempat pemain sudah menurunkan kartunyas, selesailah satu putaran permainan. Keempat kartu yang 
dimainkan ini disebut 1 trik. Karena setiap pemain memegang 13 kartu, dan semuanya harus dimainkan, maka secara keseluruhan ada 13 trik yang dimainkan.

Permainan berakhir apabila seluruh kartu telah selesai dimainkan. Hasil permainan bergantung pada trick yang didapatkan oleh declarer, apabila memenuhi kontrak, maka declarer akan mendapat point, sebaliknya, apabila kontrak down, defender akan mendapat point. Finest adalah sebuah cara untuk memenangkan sebuah trik menggunakan kartu yang tidak termasuk tinggi.

\section{h. Scorer Shet/Pensekoran Nilai}

Contoh pensekoran dari kontrak 1 NT declarer menyelesaikan tugas dengan baik dengan mengumpulkan 7 trick dan mendapatkan nilai 90 .

Tabel 2.7 Tabel Scorer menurut Iskandar (2004: 29).

\begin{tabular}{|c|c|c|c|c|c|}
\hline NT & NILAI & S/H & NILAI & D/C & NILAI \\
\hline 7 & 90 & 7 & 80 & 7 & 70 \\
\hline 8 & 120 & 8 & 110 & 8 & 90 \\
\hline 9 & 400 & 9 & 140 & 9 & 110 \\
\hline 10 & 430 & 10 & 420 & 10 & 130 \\
\hline 11 & 460 & 11 & 450 & 11 & 400 \\
\hline 12 & 490 & 12 & 480 & 12 & 420 \\
\hline 13 & 520 & 13 & 510 & 13 & 440 \\
\hline
\end{tabular}

Tabel 2.8 Tabel Score Sheet menurut Iskandar, (2004: 29)

\begin{tabular}{|c|c|c|c|c|c|}
\hline \multirow{2}{*}{ Board } & \multicolumn{2}{|c|}{ Kontrak } & \multirow{2}{*}{ Hasil } & \multicolumn{2}{|r|}{ Skor } \\
\hline & US & TB & & US & TB \\
\hline 1 & INT & - & 7 & 90 & - \\
\hline 2 & & & & & \\
\hline 3 & & & & & \\
\hline 4 & & & & & \\
\hline 5 & & & & & \\
\hline 6 & & & & & \\
\hline 7 & & & & & \\
\hline 8 & & & & & \\
\hline
\end{tabular}

\section{METODE PENELITIAN}

Penelitian ini bertujuan untuk mendeskripsikan fenomena permainan bridge di Kabupaten Jember, permasalahannya, pola pembelajaran, peningkatan kemampuan bermain, baik pemain maupun pelatih. Pendekatan yang dilakukan dalam penelitian ini 
adalah pendekatan kualitatif karena (1) peneliti bertindak sebagai instrumen utama, karena disamping sebagai pengumpul data dan penganalisis data, peneliti juga terlibat langsung dalam proses penelitian, (2) mempunyai latar alami (natural setting), data yang diteliti dan dihasilkan akan dipaparkan sesuai dengan yang terjadi di lapangan, (3) hasil penelitian bersifat deskriptif, karena data yang dikumpulkan bukan berupa angkaangka melainkan berupa kata-kata dan kalimat, (4) lebih mementingkan proses dari pada hasil, (5) adanya batas masalah yang ditemukan dalam fokus penelitian, dan (6) analisis data cenderung bersifat induktif. Hal ini sesuai dengan pendapat Moleong (2002:48).

Penelitian kualitatif memiliki karakteristik deskriptif maksudnya, dalam penelitian kualitatif, data yang dikumpulkan berupa kata-kata, gambar, dan bukan angka-angka. Laporan penelitian akan berisi pola-pola komunikasi untuk memberi gambaran penyajian laporan tersebut. Data tersebut berasal dari naskah wawancara, catatan lapangan, foto, dokumen pribadi, catatan atau memo dan dokumen penting lainnya. Data yang dikumpulkan dalam penelitian ini berisi informasi perkembangan atau keadaan permainan mini bridge. Penelitian ini akan dilaksanakan di GABSI Kabupaten Jember.

Dalam penelitian ini digunakan teknik pengumpulan data yaitu teknik dokumentasi, yakni mengambil sumber-sumber tertulis, sebagaimana yang diungkapkan oleh Arikunto (2006: 131) bahwa dalam mengadakan penelitian yang bersumber pada tulisan, maka teknik yang dipakai dalam pengumpulan data adalah teknik dokumentasi. Teknik dokumentasi adalah pengumpulan data dari sumber yang berupa catatan, data dalam buku, majalah dan lainnya. (Arikunto, 2006: 253).

Selain itu, metode pengumpulan data lainnya adalah observasi, wawancara dan pencatatan. Observasi atau pengamatan proses belajar misalnya tingkah laku, Arikunto (2006:156) mengungkapkan bahwa mengobservasi dapat dilakukan dengan penginderaan melalui penglihatan, penciuman, pendengaran, peraba, dan pengecap. Untuk melakukan observasi dibutuhkan pedoman observasi yang berisi sebuah daftar jenis kegiatan yang mungkin timbul dan akan diamati. Wawancara adalah sebuah dialog yang dilakukan oleh pewawancara (interviewer) terhadap narasumber dalam rangka memperoleh informasi. Dalam penelitian ini yang bertindak selaku pewawancara adalah Peneliti sendiri, sedangkan guru SD Muhammadiyah Kasiyan dan siswa sebagai narasumber. Melalui wawancara, peneliti dapat kontak langsung dengan siswa sehingga mahasiswa dapat mengungkapkan pola komunikasi yang tepat dalam membangun komunikasi. Teknik pencatatan adalah mencatat semua kegiatan yang dilakukan dalam peneliitian. Teknik pencatatan diperlukan untuk merekam peristiwaperistiwa dalam penelitian agar mendapatkan data yang akurat.

Instrumen yang digunakan untuk menggali dan memperoleh data dalam penelitian ini adalah peneliti sendiri. Karena dalam penelitian kualitatif, peneliti adalah instrumen utama, sehingga perolehan data sangat tergantung pada apa yang dilakukan oleh peneliti.

Metode analisis data dalam penelitian ini adalah analisis deskriptif. Deskriptif adalah menggambarkan dan menjelaskan semua data yang natural dan alami dengan menggunakan kalimat untuk menjawab dan menjawab tujuan penelitian. 
Keabsahan data merupakan hal yang terpenting dalam penelitian. Untuk mengecek keabsahan data akan digunakan teknik pengecekan keabsahan data. teknik pengecekan keabsahan data yang digunakan dalam penelitian ini adalah (a) triangulasi, (b) ketekunan pengamatan, dan (c) pemeriksaan sejawat (Moleong, 2006:175). Trianggulasi adalah suatu teknik pemeriksaan keabsahan data dengan memanfaatkan sesuatu di luar data itu untuk keperluan pengecekan atau sebagai pembanding terhadap data. Ketekunan pengamatan dilakukan dengan cara melakukan pengamatan yang teliti, rinci, dan terus-menerus selama kegiatan pembelajaran. Kegiatan ini akan diikuti dengan kegiatan wawancara secara intensif sehingga data yang dihasilkan terhindar dari hal-hal yang tidak diinginkan, misalnya subyek berdusta, berpura-pura atau menipu.

\section{HASIL DAN PEMBAHASAN}

Berdasarkan pengumpulan data, hasil evaluasi dari pemain mini bridge (uji coba tahap I atau kelompok kecil), masing-masing dari aspek tersebut akan dideskripsikan pada tabel berikut:

Tabel 4.9 Analisis Data Dari Pemain Mini Bridge (Uji Coba Tahap I atau Kelompok Kecil)

\begin{tabular}{|c|c|c|}
\hline No. & Aspek & Kriteria \\
\hline 1. & $\begin{array}{l}\text { Bagaimana tingkat kemampuan pemain dalam } \\
\text { menguasai latihan mini bridge? }\end{array}$ & - valid $(81.25 \%)$ \\
\hline 2. & $\begin{array}{l}\text { Bagaimana tingkat kemampuan pemain dalam } \\
\text { menguasai latihan menghitung point? }\end{array}$ & - cukup valid (68.75\%) \\
\hline 3. & $\begin{array}{l}\text { Bagaimana tingkat kemampuan pemain dalam } \\
\text { menguasai latihan nama kartu? }\end{array}$ & - cukup valid $(75.00 \%)$ \\
\hline 4. & $\begin{array}{l}\text { Bagaimana tingkat kemampuan pemain dalam } \\
\text { menguasai latihan menentukan kontrak? }\end{array}$ & - cukup valid $(68.75 \%)$ \\
\hline 5. & $\begin{array}{l}\text { Bagaimana tingkat kemampuan pemain dalam } \\
\text { menguasai materi permainan mini bridge kontrak } \\
\text { game? }\end{array}$ & - cukup valid $(62.50 \%)$ \\
\hline 6. & $\begin{array}{l}\text { Bagaimana kemenarikan kontrak } \\
\text { tidak game bagi pemain? }\end{array}$ & - cukup valid $(75,00 \%)$ \\
\hline 7. & $\begin{array}{l}\text { Bagaimana kemenarikan latihan } \\
\text { Truff bagi pemain? }\end{array}$ & - cukup valid (68.75\%) \\
\hline 8. & $\begin{array}{l}\text { Bagaimana kemenarikan latihan } \\
\text { kontrak NT bagi pemain? }\end{array}$ & - cukup valid $(75,00 \%)$ \\
\hline 9. & $\begin{array}{l}\text { Bagaimana kemenarikan latihan } \\
\text { menjadi Declarer/ bos } \\
\text { bagi pemain? }\end{array}$ & - cukup valid (75.00\%) \\
\hline 10. & $\begin{array}{l}\text { Bagaimana kemenarikan materi } \\
\text { teknik menaruk lead? }\end{array}$ & cukup valid (68.75\%) \\
\hline
\end{tabular}




\begin{tabular}{|l|l|l|}
\hline 11. & $\begin{array}{l}\text { Bagaimana kemenarikan materi } \\
\text { latihan menjadi dummy? } \\
\text { bagi pemain }\end{array}$ & cukup valid (68.75\%) \\
\hline 12. & $\begin{array}{l}\text { Bagaimana kesesuaian latihan Mini bridge } \\
\text { dengan point 25 oleh declarer? }\end{array}$ & cukup valid (75.00\%) \\
\hline
\end{tabular}

Berdasarkan tabel 4.9 hasil analisis evaluasi pemain mini bridge diketahui jumlah total skor responden $\left(\sum \mathrm{X}\right)$ adalah 166 dan jumlah total keseluruhan skor responden $\left(\sum X 1\right)$ adalah 224 . Sehingga, persentasenya adalah $74,11 \%$.

Data hasil penilaian tahap II tersebut di atas yang berbentuk data kualitatif, kemudian dirubah menjadi data kuantitatif seperti pada tabel 4.20 berikut ini.

\section{Tabel 4.20 Data Pemain Hasil Uji Coba Tahap II (Kelompok Besar)}

\begin{tabular}{|c|l|c|c|c|c|c|c|c|c|}
\hline \multirow{2}{*}{$\begin{array}{c}\text { N } \\
0\end{array}$} & \multicolumn{1}{|c|}{ ASPEK } & \multicolumn{1}{|c|}{ X } & X & X & X & X & X & X & X \\
& & 1 & 2 & 3 & 4 & 5 & 6 & 7 & 8 \\
\hline 1 & $\begin{array}{l}\text { Bagaimana tingkat kemampuan } \\
\text { pemain dalam menguasai latihan } \\
\text { mini bridge? }\end{array}$ & 4 & 3 & 3 & 3 & 3 & 3 & 4 & 3 \\
\hline 2 & $\begin{array}{l}\text { Bagaimana tingkat kemampuan } \\
\text { pemain dalam menguasai latihan } \\
\text { menghitung point? }\end{array}$ & 3 & 3 & 3 & 3 & 3 & 3 & 4 & 3 \\
\hline 3 & $\begin{array}{l}\text { Bagaimana tingkat kemampuan } \\
\text { pemain dalam menguasai latihan } \\
\text { nama kartu? }\end{array}$ & 4 & 4 & 3 & 3 & 3 & 3 & 4 & 3 \\
\hline 4 & $\begin{array}{l}\text { Bagaimana tingkat kemampuan } \\
\text { pemain dalam menguasai latihan } \\
\text { menentukan kontrak? }\end{array}$ & 3 & 3 & 3 & 3 & 3 & 3 & 4 & 3 \\
\hline 5 & $\begin{array}{l}\text { Bagaimana tingkat kemampuan } \\
\text { pemain dalam menguasai materi } \\
\text { permainan mini bridge kontrak } \\
\text { game? }\end{array}$ & 3 & 4 & 4 & 4 & 3 & 4 & 4 & 3 \\
\hline 6. & $\begin{array}{l}\text { Bagaimana kemenarikan kontrak } \\
\text { tidak game bagi pemain? }\end{array}$ & 4 & 4 & 4 & 4 & 4 & 4 & 4 & 4 \\
\hline 7. & $\begin{array}{l}\text { Bagaimana kemenarikan latihan } \\
\text { Truff bagi pemain? }\end{array}$ & 3 & 3 & 4 & 3 & 3 & 4 & 4 & 3 \\
\hline 8. & $\begin{array}{l}\text { Bagaimana kemenarikan latihan } \\
\text { kontrak NT bagi pemain? }\end{array}$ & 3 & 4 & 4 & 3 & 3 & 3 & 3 & 4 \\
\hline 9. & $\begin{array}{l}\text { Bagaimana kemenarikan latihan } \\
\text { menjadi Declarer/ bos } \\
\text { bagi pemain? }\end{array}$ & 3 & 4 & 3 & 3 & 3 & 4 & 4 & 4 \\
\hline
\end{tabular}




\begin{tabular}{|c|l|c|c|c|c|c|c|c|c|}
\hline 10 & $\begin{array}{l}\text { Bagaimana kemenarikan materi } \\
\text { teknik menaruk lead? }\end{array}$ & 4 & 4 & 3 & 4 & 4 & 4 & 4 & 4 \\
\hline 11 & $\begin{array}{l}\text { Bagaimana kemenarikan materi } \\
\text { latihan menjadi dummy? } \\
\text { bagi pemain }\end{array}$ & 4 & 3 & 3 & 3 & 3 & 4 & 3 & 4 \\
\hline
\end{tabular}

\begin{tabular}{|c|l|c|c|c|c|c|c|c|c|}
\hline \multirow{2}{*}{ N0 } & \multicolumn{1}{|c|}{ ASPEK } & \multicolumn{10}{|c|}{ SKOR } \\
\cline { 3 - 9 } & & X & X & X & X & X & X & X & X \\
12. & $\begin{array}{l}\text { Bagaimana tingkat kemampuan } \\
\text { pemain dalam menguasai } \\
\text { latihan mini bridge? }\end{array}$ & 4 & 4 & 3 & 3 & 4 & 4 & 4 & 4 \\
\hline 13. & $\begin{array}{l}\text { Bagaimana tingkat kemampuan } \\
\text { pemain dalam menguasai } \\
\text { latihan menghitung point? }\end{array}$ & 4 & 4 & 4 & 3 & 4 & 4 & 4 & 4 \\
\hline 14. & $\begin{array}{l}\text { Bagaimana tingkat kemampuan } \\
\text { pemain dalam menguasai } \\
\text { latihan nama kartu? }\end{array}$ & 4 & 4 & 4 & 3 & 4 & 4 & 4 & 4 \\
\hline
\end{tabular}

Berikut ini adalah analisis data yang dilakukan berdasarkan data hasil evaluasi dari pemain mini bridge (uji coba tahap II atau kelompok besar), masing-masing dari aspek tersebut akan dideskripsikan pada tabel berikut.

Tabel 4.21 Analisis Data Dari Pemain Mini Bridge (Uji Coba Tahap II)

\begin{tabular}{|l|l|l|}
\hline No. & \multicolumn{1}{|c|}{ Aspek } & \multicolumn{1}{|c|}{ Kriteria } \\
\hline 1. & $\begin{array}{l}\text { Bagaimana tingkat kemampuan pemain dalam } \\
\text { menguasai latihan mini bridge? }\end{array}$ & $\bullet$ valid (84.61\%) \\
\hline 2. & $\begin{array}{l}\text { Bagaimana tingkat kemampuan pemain dalam } \\
\text { menguasai latihan menghitung point? }\end{array}$ & $\bullet$ valid (82.69\%) \\
\hline 3. & $\begin{array}{l}\text { Bagaimana tingkat kemampuan pemain dalam } \\
\text { menguasai latihan nama kartu? }\end{array}$ & $\bullet$ valid (82.69\%) \\
\hline 4. & $\begin{array}{l}\text { Bagaimana tingkat kemampuan pemain dalam } \\
\text { menguasai latihan menentukan kontrak? }\end{array}$ & $\bullet$ valid (80.76\%) \\
\hline 5. & $\begin{array}{l}\text { Bagaimana tingkat kemampuan pemain dalam } \\
\text { menguasai materi permainan mini bridge kontrak } \\
\text { game? }\end{array}$ & $\bullet$ valid (84.61\%) \\
\hline 6. & $\begin{array}{l}\text { Bagaimana kemenarikan kontrak } \\
\text { tidak game bagi pemain? }\end{array}$ & $\bullet$ valid(98.07\%) \\
\hline 7. & $\begin{array}{l}\text { Bagaimana kemenarikan latihan } \\
\text { Truff bagi pemain? }\end{array}$ & $\bullet$ valid (82.69\%) \\
\hline 8. & $\begin{array}{l}\text { Bagaimana kemenarikan latihan } \\
\text { kontrak NT bagi pemain? }\end{array}$ & $\bullet$ cukup valid \\
\hline
\end{tabular}




\begin{tabular}{|l|l|l|}
\hline 9. & $\begin{array}{l}\text { Bagaimana kemenarikan latihan } \\
\text { menjadi Declarer/ bos } \\
\text { bagi pemain? }\end{array}$ & $\bullet$ valid $(90.38 \%)$ \\
\hline 10 & $\begin{array}{l}\text { Bagaimana kemenarikan materi } \\
\text { teknik menaruk lead? }\end{array}$ & $\bullet$ valid (98.07\%) \\
\hline 11 & $\begin{array}{l}\text { Bagaimana kemenarikan materi } \\
\text { latihan menjadi dummy? } \\
\text { bagi pemain }\end{array}$ & $\begin{array}{l}\text { cukup valid } \\
(75.00 \%)\end{array}$ \\
\hline 12 & $\begin{array}{l}\text { Bagaimana kesesuaian latihan Mini bridge } \\
\text { dengan point 25 oleh declarer? }\end{array}$ & $\bullet$ valid $(96,15 \%)$ \\
\hline
\end{tabular}

Berdasarkan tabel 4.20 hasil analisis evaluasi Pemain mini bridge (Uji Coba Tahap II) bahwa diketahui jumlah total skor responden $\left(\sum X\right)$ adalah 637 dan jumlah total keseluruhan skor responden $\left(\sum X 1\right)$ adalah 728. Sehingga, persentasenya adalah 87,50 $\%$.

\section{KESIMPULAN}

Berdasarkan hasil analisis data di atas, fenomena perkembangan permainan mini bridge di kabupaten Jember, baik pelatih dan pemain mini bridge mengalami peningkatan dan kemajuan. Pada tahap I kriteria yang ditentukan dapat dikatakan bahwa fenomena pengembangan permainan mini bridge di GABSI Jember memenuhi kriteria cukup valid, yaitu $74,11 \%$, dan dari hasil uji coba tahap II memenuhi kriteria valid, yaitu $87,50 \%$ ). Sehingga dapat disimpulkan bahwa permasalahan pengembangan permainan mini bridge menurun, beberapa permasalahan bisa diatasi. Pola pembelajaran permainan mini bridge terbukti semakin membaik, dapat digunakan dan dipraktikkan dalam proses pembelajaran permainan mini bridge secara lebih mudah. Prestasi atau peningkatan kemampuan pemain juga meningkat.

\section{DAFTAR PUSTAKA}

Arikunto, Suharsimi. 2006. Prosedur Penelitian: Suatu Pendekaan Praktik. Jakarta: Rineka Cipta

Andre, Mini Bridge http://andreprikitiew.wordpress.com/2011/10/18/minibridge/ (diunduh 1 Juli 2012).

Asbi, Taufik. (2010). Belajar Bridge. Jakarta: PT Media Indo Cipta.

Citra umbara, (2007). Undang-Undang Republik Indonesia Nomor 3 Tahun 2005 tentang Sistem Keolahragaan Nasional. Bandung: Citra Umbara.

Homboku. (2004). Belajar Bermain Mini dan Bridge. Jember: Gabungan Bridge Jember. 
Iskandar. (2004). Mini Bridge. Jakarta: Gabungan Bridge Seluruh Indonesia.

Moleong, Lexy, J. 1996. Metode Penelitian Kualitatif. Bandung: Rosda Karya

Zona,Mini Bridge Jalan Pintas Belajar Bridge http:zonabridge.blogspot.com/2011/05 minibridge (di unduh 05 Oktober 2011). 